$$
\text { JOES } \begin{aligned}
& \begin{array}{l}
\text { Journal } \\
\text { of Educational } \\
\text { Study }
\end{array} \\
& \text { Studuction }
\end{aligned}
$$

ISSN 2798-0650

Volume 1 Issue 32021

DOI: $10.36663 /$ joes.v1i3.168

\title{
The Teachers' Acceptance of Technology in a Remote English Teaching at SMA Negeri 4 Singaraja
}

\author{
Kadek Wira Arya Dharma, Universitas Pendidikan Ganesha, Indonesia
}

wiraaryad@gmail.com

\begin{abstract}
This study is aimed to describe the English teachers' acceptance of technology in remote English teaching. SMA Negeri 4 Singaraja is one of the senior high school that implementing remote English remote English teaching during the pandemic. Furthermore, in order to find out the English teachers' acceptance in remote English teaching in SMA Negeri 4 Singaraja, Technology Acceptance Model (TAM) theory is used. The samples of this study were the 7 English of SMA Negeri 4 Singaraja. In order to collect the data, questionnaire was used. The data was collected from survey which was analyzed quantitatively. The result of this study showed that English teachers' acceptance of technology in remote English teaching at SMA Negeri 4 Singaraja was neutral, which means they were either accepting remote English teaching or denying remote English teaching. However, their neutral acceptance was considered more to positive because several factors such as perceive ease of use and perceive of usefulness.
\end{abstract}

Keywords: English Teaching, Remote Teaching, Technology Acceptance Model

\section{Introduction}

Human resources and technology development help to improve education to the next level Buselic (2012). Earlier, education can be held face-to-face like conventional or online with the help of technologies Ekmekçi (2015). Technology in education gives teachers benefit to make their teaching job become effortless and improving Abed (2019) Human resources and technology development help to improve education to the next level Buselic (2012). Earlier, education can be held face-to-face like conventional or online with the help of technologies according to Ekmekçi (2015). With the help of technology, the learning process happens at any place and at any time (Hamiti \& Reka, 2012). To hold the learning process outside the classroom required a Learning Management System (LMS). Moodle, Google Classroom, and Schoology are the example of LMS Costa et al. (2012). LMS helps the success of remote learning in a specific condition Baccalaureate (2020). For several months earlier and still going on, Indonesia and countries all over the world are affected by the corona virus 2019 outbreak (COVID-19) Padmo et al. (2020), this also impacts the continuity of the educational system, especially in Indonesia. To overcome this situation, the Indonesian minister and the Indonesian government had decided on several protocols to keep the continuity of the educational process Hermawan et al. (2018). With remote English teaching it can be hold online, Remote English teaching is a process of learning in which the learning happens not 


\section{JOES $\mid \begin{aligned} & \text { Journal } \\ & \text { of Educational } \\ & \text { Study }\end{aligned}$}

ISSN 2798-0650

Volume 1 Issue 32021

DOI: $10.36663 /$ joes.v1i3.168

at the same place or outside the classroom (Cook \& Sonnenberg, 2014), and it requires the technology to conduct the learning process Ekmekçi (2015).

Remote English teaching can be conducted with applications or software such as Schoology, Moodle, and Google Classroom according to Jati (2013). Implementing remote teaching in the English language teaching context is a different term than traditional English teaching, the teachers need to transfer the teaching to the online platform Sun (2011). In conducting remote teaching or online learning there is always a challenges Żammit (2020) The teachers need to think that the implementation of ELT in remote teaching is using a different strategy and media. Before conducting the teaching in remote teaching, teachers need to transfer the materials, slides, pictures, and videos to the platform (LMS). Another thing that needs to be done is that the teachers need to post plentiful online exercises such as multiple choice and short answers. True/false, and fill in the blank according to the learning objectives. When the students are required to submit the oral work, they are told to create audio files or video files to the LMS. Teachers' role is significant in remote English teaching because they are the person who will give feedback, comment, and suggestion to the students Pawan et al. (2016). Another related research was conducted by Buselic (2012) and discussed the concept and contribution of distance learning. This study aimed to review distance-learning or online learning in the context of present definitions, technologies, opportunities, challenges, concepts, and contributions Mohammadi et al. (2011). It is quickly becoming a common part of the new educational system in both developing and developed countries. The result of this study was that online courses would effectively be running if there is a learning system integrated with a forum, material, submission, etc. Online courses provide more flexibility and freedom of self-directed learning for the students. Distance learning is not a contemporary learning trend. Still, it will develop better because it is a future learning format that provides flexibility and18 no distance requirement because it can be accessed everywhere, at considerable cost, and student-centered.

Moreover, the researcher intends to conduct research about the English teachers' acceptance of technology in remote English teaching at SMAN 4 Singaraja. It was chosen because SMA Negeri 4 Singaraja had ever used remote English teaching platform Schoology as an addition, and lately SMA Negeri 4 Singaraja had implement remote English teaching fully because the covid-19 outbreak. The sudden implementation of remote English teaching leads the researcher to find out the acceptance of technology of English teachers, in remote English teaching and to find out its challenges. Based on preliminary research with English teachers at SMAN 4 Singaraja by interview. It was found that the implementation of remote English teaching seems unusual because they were used to teach and learn in offline class (A. Sun \& Chen, 2016). Then in the sudden implementation of remote English teaching, some seem astonished with the system and the learning method. The previous habit of teaching and learning were changed into teaching and learning remotely via gadget with LMS as a media. For some of the English teachers, this is quite ambiguous. This issue leads the researcher to conduct the study to find out their acceptance of technology level in remote English teaching. The purpose of finding out the acceptance of technology level of English teachers was to describe whether remote English teaching is effective. 


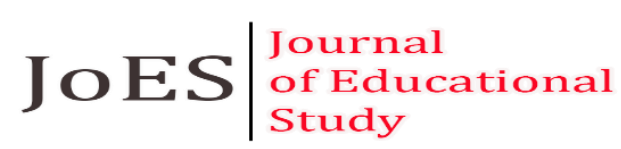

ISSN 2798-0650

Volume 1 Issue 32021

DOI: $10.36663 /$ joes.v1i3.168

To underlie this study Technology Acceptance Model Davis et al. (1989) theory was used. TAM was used to find out the user acceptance in the use of technology Davis et al. (1989). There are two variables that can determine user acceptance, namely perceived usefulness and perceived ease of use. TAM is an adaptation theory from the Theory of Reasoned Action (TRA) according to Witriyanti et al. (2016), this theory explains that a system user tends to use a system if the system can be useful and can help them ease their job Davis et al. (1989). The purpose of the technology acceptance model (TAM) aims to explain and presume the user's acceptance of technology, specifically remote teaching (Olushola \& Abiola, 2017). The technology acceptance model is a theory that can explain and presume the users' acceptance toward remote teaching. A study by (Yuen \& Ma, 2008) exploring teacher acceptance of e-learning technology believes that TAM is a better model used to find the teachers' acceptance of e-learning technology. The study is aimed to predict the teachers' acceptance of e-learning technology. In conducting the study, they involved 152 teachers. The result shows that one of the TAM dimensions, which is perceived ease of use, is significant in giving data of teachers' acceptance of e-learning technology, besides the other one is quite significant (PU dimension). Teachers' acceptance of e-learning technology can be predicted properly using the Technology acceptance model (TAM) and its dimensions.

\section{Method}

This study uses a descriptive quantitative design, and 7 English teachers was involved in this study. In this study a questionnaire was used in order to collect the data, the questionnaire was adapted from TAM Davis et al. (1989) and then modified to suit the sample and the setting. After conducting content validity, two judges stated that 26 out of 26 items in this questionnaire was relevant to be used in the survey. The survey result, which uses a questionnaire, were analyzed in the form of the ideal mean. There are several steps to analyze the quantitative data. The first is collecting the data from the questionnaire. Second, the data tabulation is displayed in Microsoft excel. Third, the data of the questionnaires analyzed using descriptive statistics, central tendency measurement (mean), and dispersion measurement (Standard deviation), and each dimension's frequency is also analyzed. It is analyzed using the SPSS program, and the criteria can be seen in the table below. The last step is drawing a conclusion by determining the result of the mean score into the categorization level.

\section{Findings}

Table 1. English Teachers' Technology Acceptance in Remote English teaching

\begin{tabular}{|c|l|c|c|c|}
\hline No & \multicolumn{1}{|c|}{ Dimension } & Interval & Mean Score & Qualification \\
\hline 1 & Overall Dimension & $73.59<\mathrm{M}<77.41$ & 75.5 & Neutral \\
\hline 2 & Perceive of Usefulness & $37.35<\mathrm{M}<46.65$ & 43.57 & Neutral \\
\hline 3 & Perceive Ease of Use & $32<\mathrm{M}<40$ & 33.43 & Neutral \\
\hline
\end{tabular}

The previous calculation in Table 2 showed that after the calculation they were qualified as neutral. The mean score of the technology acceptance of English teachers in remote English teaching in SMA Negeri 4 Singaraja was qualified as neutral. It means that the English teachers in 


\section{JOES $\mid \begin{aligned} & \text { Journal } \\ & \text { of Educational } \\ & \text { Study }\end{aligned}$}

ISSN 2798-0650

Volume 1 Issue 32021

DOI: $10.36663 /$ joes.v1i3.168

SMA Negeri 4 Singaraja accept remote English teaching as the technology that can ease their job. On the other hand, they also did not accept remote English teaching. The mean score of the technology acceptance of English teachers in remote English teaching in PU dimension was in the qualification of neutral. It means that the English teachers believe that the remote English teaching could improve or decrease their job performance. The mean score of the technology acceptance of English teachers in remote English teaching was in the qualified of neutral. From the previous calculation, it can be described that the English teachers believe that remote English teaching could make their job become effortless and at any time it can burden their job.

\section{Discussions}

Based on the finding above, it can be seen that the English teachers acceptance of technology in remote English teaching was neutral which means they either accepting remote English teaching or denying remote English teaching, it was supported with A study by (Yuen \& Ma, 2008) exploring teacher acceptance of e-learning technology believes that TAM is a better model used to find the teachers' acceptance of e-learning technology (Schwarz \& Chin, 2007). The study is aimed to predict the teachers' acceptance of e-learning technology. In conducting the study, they involved 152 teachers. The result shows that one of the TAM dimensions, which is perceived ease of use, is significant in giving data of teachers' acceptance of e-learning technology, besides the other one is quite significant (PU dimension). Teachers' acceptance of e-learning technology can be predicted properly using the Technology acceptance model (TAM) and its dimensions. It can be inferred that to dig more about the acceptance of technology two dimensions of TAM can help (Al-busaidi \& Alshihi, 2010).

In perceive of usefulness dimension, the English teacher's acceptance in remote English teaching was neutral which means they believe remote English teaching can improve their job performance but it can also decrease their job performance. Another related research was conducted by (Buselic, 2012) and discussed the concept and contribution of distance learning. This study aimed to review distance-learning or online learning in the context of present definitions, technologies, opportunities, challenges, concepts, and contributions. The result of this study was that online courses would effectively be running if there is a learning system integrated with a forum, material, submission, etc. Another related study was conducted by Al-Hujran et al. (2013) about the challenges to E-learning success. This study was proposed to reports the student's perspective about the E-learning paradigm and tools. The result of this study was, there were several issues which appear behind the success of E-learning such as lack of technology skill and ability. It can be inferred that Remote English teaching can improve their job performance and can decrease their job performance because in remote English teaching there were benefit and challenges (Yuen \& Ma, 2008).

In perceive ease of use dimension, English teacher's acceptance in remote English teaching was neutral which means they either believe remote English teaching can make the teaching become effortless and they also believe that remote English teaching can burden their teaching Yiong et al. (2008). A study about E-learning issues and challenges was conducted by Rana et al. (2014). This study aimed to identify the issues and challenges of E-learning and was conducted in New Delhi. This study's result was that technology plays a significant role in E-learning. However, 


\section{JOES $\mid \begin{aligned} & \text { Journal } \\ & \text { of Educational } \\ & \text { Study }\end{aligned}$}

ISSN 2798-0650

Volume 1 Issue 32021

DOI: $10.36663 /$ joes.v1i3.168

it comes to several issues such as technological challenges Gillett-Swan (2017) also in tune with this, the development of new forms of learning community and interactive learning and developing new knowledge facilities for e-learning. Young (2010) conducted research about student's views of the effectiveness of online teaching in higher education this study aims to investigate the student's views of online teaching in higher education courses. The result shows that effective online learning instructors should be able to provide corrective feedback encouragement, motivating the students to focus on their educational achievement and goals. Online course's most highlighted advantages are their flexibility, students and instructors admit this. It can be seen that, they believe that remote teaching can make their job effortless because remote English teaching is flexible, and they believe Remote English teaching can burden them because there were several challenges in implementing it.

After several findings and theories, it was found that the English teachers' acceptance of technology was neutral, and in each dimension of TAM their acceptance of technology was also neutral. According to Rana et al. (2014) was because the teachers faced several challenges in the implementation of remote English teaching. However, according to Young (2010) the English teacher accepting remote English teaching because of its benefits such as the flexibility. Moreover, the findings of this study is expected to be as a reflection and improvement to the decision maker to improve the implementation of remote English teaching

\section{Conclusions and Suggestions}

This study aims to describe the English teachers' technology acceptance in remote English teaching. Regarding the result of the questionnaire, it was found that English teachers' technology acceptance in remote English teaching was neutral. English teachers' technology acceptance in remote English teaching was in between accepting or denying it. Two dimensions from TAM theory by (Davis, 1989) help to explain more about their neutral technology acceptance in remote English teaching. Moreover, in the future remote English teaching is expected to have better impact to the English teaching and even the style can be implement in the other subject with adjustment.

\section{References}

Abed, E. K. (2019). Electronic learning and its benefits in education. Eurasia Journal of Mathematics, Science and Technology Education, 15(3). https://doi.org/10.29333/ejmste/102668

Al-busaidi, K. A., \& Alshihi, H. (2010). Instructors 'Acceptance of Learning Management Systems : A Theoretical Framework. January. https://doi.org/10.5171/2010.862128

Al-Hujran, O., Aloudat, A., Al-Hennawi, H., \& Nabeel Ismail, H. (2013). Challenges to E-learning Success:The Student Perspective. March. https://doi.org/10.2991/icibet.2013.226

Baccalaureate, I. O. (2020). Online learning, teaching and education continuity planning for schools. International Baccalaureate, 1-13. ibo.org

Buselic, M. (2012). Distance Learning - concepts and contributions. Oeconomica Jadertina, 1, 23-34.

Cook, C. W., \& Sonnenberg, C. (2014). Technology and Online Education Models For Change. 


\section{JOES $\begin{aligned} & \begin{array}{l}\text { Journal } \\ \text { of Educational } \\ \text { Study }\end{array} \\ & \text { Etudution }\end{aligned}$}

ISSN 2798-0650

Volume 1 Issue 32021

DOI: 10.36663/joes.v1i3.168

7(3), 171-188.

Costa, C., Alvelos, H., \& Teixeira, L. (2012). The Use of Moodle e-learning Platform: A Study in a Portuguese University. Procedia Technology, 5(December), 334-343. https://doi.org/10.1016/j.protcy.2012.09.037

Davis, F. D. (1989). Perceived usefulness, perceived ease of use, and user acceptance of information technology. MIS Quarterly: Management Information Systems, 13(3), 319-339. https://doi.org/10.2307/249008

Davis, F. D., Bagozzi, R. P., \& Warshaw, P. R. (1989). User Acceptance of Computer Technology: A Comparison of Two Theoretical Models. Management Science, 35(8), 982-1003. https://doi.org/10.1287/mnsc.35.8.982

Ekmekçi, E. (2015). Distance-education in Foreign Language Teaching: Evaluations from the Perspectives of Freshman Students. Procedia - Social and Behavioral Sciences, 176, 390397. https://doi.org/10.1016/j.sbspro.2015.01.487

Gillett-Swan, J. (2017). The Challenges of Online Learning: Supporting and Engaging the Isolated Learner. Journal of Learning Design, 10(1), 20. https://doi.org/10.5204/jld.v9i3.293

Hamiti, M., \& Reka, B. (2012). Teaching with Technology. Procedia - Social and Behavioral Sciences, 46, 1171-1176. https://doi.org/10.1016/j.sbspro.2012.05.269

Hermawan, H. D., Deswila, N., \& Yunita, D. N. (2018). Implementation of ICT in Education in Indonesia during 2004-2017. Proceedings - 2018 International Symposium on Educational Technology, ISET 2018, July 2018, 108-112. https://doi.org/10.1109/ISET.2018.00032

Jati, G. (2013). Learning Management System (moodle) and E-Learning Content Development. Jurnal Sosioteknologi, 12(28), 277-289. https://doi.org/10.5614/sostek.itbj.2013.12.28.3

Mohammadi, N., Ghorbani, V., \& Hamidi, F. (2011). Effects of e-learning on language learning. Procedia Computer Science, 3, 464-468. https://doi.org/10.1016/j.procs.2010.12.078

Olushola, T., \& Abiola, J. O. (2017). The Efficacy of Technology Acceptance Model : A Review of Applicable Theoretical Models in Information Technology Researches. 4(11), 70-83.

Padmo, D., Terbuka, U., Ardiasih, L. S., \& Terbuka, U. (2020). Online Learning During the Covid19 Pandemic and Its Effect on Future Education in Indonesia. November. https://doi.org/10.51432/978-1-8381524-0-6

Pawan, F., Wiechart, K. A., Warren, A. N., Park, J., \& Association, T. I. (2016). Pedagogy and Practice for Online English Language Teacher Education. TESOL Press, August 2018, 1011.

http://survey.hshsl.umaryland.edu/?url=http://search.ebscohost.com/login.aspx?direct=true $\& \mathrm{db}=$ eric $\& A N=E D 571293 \&$ site $=$ ehost -

live\%0Ahttp://bookstore.tesol.org/ItemDetail?iProductCode=14031\&Category=TEACHED

Rana, H., Rajiv, R., \& Lal, M. (2014). E-learning: Issues and Challenges. International Journal of Computer Applications, 97(5), 20-24. https://doi.org/10.5120/17004-7154

Schwarz, A., \& Chin, W. (2007). Looking forward: Toward an understanding of the nature and definition of IT acceptance. Journal of the Association for Information Systems, 8(4), 230243. https://doi.org/10.17705/1jais.00123

Sun, A., \& Chen, X. (2016). Online education and its effective practice: A research review. Journal of Information Technology Education: Research, 15(2016), 157-190. 


\section{JOES $\mid \begin{aligned} & \text { Journal } \\ & \text { of Educational } \\ & \text { Study }\end{aligned}$}

ISSN 2798-0650

Volume 1 Issue 32021

https://doi.org/10.28945/3502

Sun, S. Y. H. (2011). Online language teaching: The pedagogical challenges. Knowledge Management and E-Learning, 3(3), 428-447. https://doi.org/10.34105/j.kmel.2011.03.030

Witriyanti, M., Yasa, K., \& Sukaatmadja, G. (2016). Aplikasi Model TAM(Technology Acceptance Model) Pada Perilaku Pengguna https://www.google.gr/_/chrome/newtab?espv=2\&ie=UTF-8

Yiong, B. L. C., Sam, H. K., \& Wah, T. K. (2008). Acceptance of e-learning among distance learners: A malaysian perspective. ASCILITE 2008 - The Australasian Society for Computers in Learning in Tertiary Education, 541-551.

Young, S. (2010). American Journal of Distance Student Views of Effective Online Teaching in Higher Education. December 2014, 37-41. https://doi.org/10.1207/s15389286ajde2002

Yuen, A. H. K., \& Ma, W. W. K. (2008). Exploring teacher acceptance of e-learning technology. Asia-Pacific Journal of Teacher Education, 36(3), 229-243. https://doi.org/10.1080/13598660802232779

Żammit, J. (2020). The Benefits and Challanges of Distance Education in Teaching Maltese as a Second Language to Adults. 14(December 2020), 273-299. 